\title{
Optimization of flotation, DNA extraction and PCR methods for detection of Toxoplasma gondii oocysts in cat faeces
}

\author{
Jacek Sroka ${ }^{1, A-D, F}$, Jacek Karamon ${ }^{1, C, E}$, Jacek Dutkiewicz ${ }^{2, C-F}$, Angelina Wójcik-Fatla ${ }^{2, C, E}$, \\ Tomasz Cencek ${ }^{1, A, C, E}$ \\ ${ }^{1}$ National Veterinary Research Institute, Puławy, Poland \\ ${ }^{2}$ Institute of Rural Health, Lublin, Poland \\ A - Research concept and design, B - Collection and/or assembly of data, C - Data analysis and interpretation, \\ $D$ - Writing the article, E - Critical revision of the article, F - Final approval of article
}

Sroka J, Karamon J, Dutkiewicz J, Wójcik-Fatla A, Cencek T. Optimization of flotation, DNA extraction and PCR methods for detection of Toxoplasma gondii oocysts in cat faeces. Ann Agric Environ Med. 2018; 25(4): 680-685. doi: 10.26444/aaem/97402

\begin{abstract}
Introduction and objective. The aim of the study was to compare the effectiveness of selected oocysts concentration methods, DNA extraction protocols and PCR assays targeting the B1 gene, for the development of procedures which would be effective and useful in laboratory practice for the detection of T. gondii in faecal samples from cats.

Materials and method. In order to compare the influence of the flotation fluids on microscopy and PCR detection of T. gondii, saturated solutions of saccharose, $\mathrm{MgSO}_{4}, \mathrm{ZnSO}_{4}$ and $\mathrm{NaNO}_{3}$ were used. To determine the sensitivity of PCR tests used: Real time PCR (RT) and nested PCR, water samples spiked with T. gondii tachyzoites and oocysts were tested. DNA was extracted using DNeasy Blood and Tissue Kit (Qiagen) (K1). The same PCR tests were used to assess the efficacy of T. gondii DNA detection in samples of cat faeces spiked with oocysts, using DNA extraction by a K1 set and a K2 set (Qlamp DNA Stool Mini Kit, (Qiagen).

Results. The initial results showed that $\mathrm{NaNO}_{3}$ was most useful as a flotation fluid due to the lack negative effect on the oocysts and amplification efficacy in PCR. The level of detection for water samples (100 $\mu$ l) was determined as 100 tachyzoites and 1-50 oocysts in RT, and 2-20 oocysts in nested PCR. The limit of detection (LD) for stool samples ( $250 \mathrm{mg})$ spiked with oocysts, where the K1 set was used, determined as 250 and 5 oocysts in RT and nested PCR, respectively. For samples extracted with the K2 set, LD in RT was determined as 1-50 oocysts (depending on the variant) and 50 oocysts in nested PCR. Conclusions. The most effective methods for detection of T. gondii in cat faeces seem to be centrifugal flotation with $\mathrm{NaNO}_{3^{\prime}}$ followed by DNA extraction with removing of inhibitors (K2 set) and Real Time PCR targeting B1 gene.
\end{abstract}

- Key words

flotation, Toxoplasma gondii, faeces, Real time PCR, nested PCR, cats, oocysts detection

\section{INTRODUCTION}

Toxoplasma gondii infection can cause a health problem, especially for pregnant women, because of the possibility of foetus malformations, and for persons with immunodeficiency, in whom pathological changes may occur in many organs or tissues. Humans can become infected with $T$. gondii mostly via the alimentary route, by eating raw meat (mainly pork) containing cysts of $T$. gondii, or by consumption other foods or water contaminated with oocysts shed by infected cats [1-4].

Methods used for the detection of oocysts in cat faeces include light microscopy, bioassay on mice and molecular techniques $[1,5]$. The sensitivity of the method based on oocysts detection under light microscopy after concentration by flotation is low [6, 7]. Moreover, the T. gondii oocysts may not be distinguished microscopically from other coccidian oocysts, especially against the Hammondia type oocysts. Thus, the molecular diagnostic of cat faeces can be superior for parasite detection $[8,9]$. Several PCR protocols have been developed for the detection of T. gondii in cat faeces $[5,10$,

Address for correspondence: Jacek Sroka, National Veterinary Research Institute, Puławy, Poland

e-mail: jacek.sroka@piwet.pulawy.pl

Received: 15.08.2018; accepted: 09.10.2018; first published:02.11.2018
11], and the highest sensitivity has been observed in assays targeting highly conserved repetitive DNA sequences, i.e. the $\mathrm{B} 1$ gene, 529-bp element (529-bp RE), and the internal transcribed spacer-1 (ITS-1) of the ribosomal RNA (rDNA) gene [11].

The use of PCR, as a method more sensitive compared to microscopy, can increase the effectiveness of detection of parasites in faeces samples.

\section{OBJECTIVE}

The aim of the study was to compare the effectiveness of selected oocysts concentration methods, DNA extraction protocols and PCR assays targeting the B1 gene, for the development of procedures which would be effective and useful in laboratory practice for the detection of T. gondii in faecal samples of cats.

\section{MATERIALS AND METHOD}

Faecal samples used in spiking experiments. Fresh cat stool samples were collected by veterinarians. Stool samples were taken from seronegative for T. gondii cats (examination 
by indirect immunofluorescence test) and checked by light microscopy for the presence of structures similar to Toxoplasma oocysts, following by faecal flotation in Sheather's sugar solution according to the method described by Dubey and Beattie (1988) [1]. Each specimen was examined in duplicate repetitions.

Toxoplasma tachyzoites and oocysts used for spiking samples. T. gondii tachyzoites were obtained from peritoneal fluid of mice inoculated with RH T. gondii strain, whereas oocysts were isolated from faeces of cats infected with PRU T. gondii strain, and then stored in $2 \%$ sulphuric acid at $4-8^{\circ} \mathrm{C}$ (oocysts kindly provided by Dr. A. Lass, Department of Tropical Parasitology, Interfaculty Institute of Maritime and Tropical Medicine in Gdynia, Medical University of Gdansk, Gdansk, Poland). Tachyzoites and oocysts were counted using a Neubauer chamber. Before the isolation of DNA, oocysts were washed as described by Shares et al. [12].

\section{Comparison of flotation and PCR effectiveness using selected flotation solutions.}

The following flotation solutions were used:

Saccharose $\left(\mathrm{C}_{2} \mathrm{H}_{22} \mathrm{O}_{11}\right.$, specific gravity (sg): 1.26). To 100 $\mathrm{ml}$ of redistilled $\mathrm{H}_{2}^{22} \mathrm{O}, 106 \mathrm{~g}$ of saccharose was added and heated to $60^{\circ} \mathrm{C}$, mixing constantly on a magnetic stirrer. After obtaining a homogeneous solution, the liquid was cooled to $4^{\circ} \mathrm{C}$.

Sodium nitrate $\left(\mathrm{NaNO}_{3}\right.$, sg: 1.30). To $500 \mathrm{ml}$ of redistilled $\mathrm{H}_{2} \mathrm{O}, 615 \mathrm{~g} \mathrm{NaNO}_{3}$ was added and mixed on a magnetic stirrer. After dissolving the salt, the solution was filled up to one liter $\mathrm{H}_{2} \mathrm{O}$.

Zinc sulphate $\left(\mathrm{ZnSO}_{4}\right.$, sg: 1.20). To $500 \mathrm{ml}$ of redist. $\mathrm{H}_{2} \mathrm{O}$, $330 \mathrm{~g} \mathrm{ZnSO}_{4}$ was added and mixed in a magnetic stirrer. After dissolving the salt, the solution was filled up to one liter $\mathrm{H}_{2} \mathrm{O}$.

Magnesium sulphate ( $\mathrm{MgSO}_{4}$ sg: 1.28). To $500 \mathrm{ml}$ of redist. $\mathrm{H}_{2} \mathrm{O}, 350 \mathrm{~g} \mathrm{MgSO}_{4}$ was added and mixed in a magnetic stirrer. After dissolving the salt, the solution was filled up to one liter $\mathrm{H}_{2} \mathrm{O}$.

Flotation, microscopy, DNA extraction and PCR examination of flotation variants. In each of the flotation variants, $0.25 \mathrm{~g}$ cat stool samples (free of Toxoplasma) were spiked with the dilutions of $T$. gondii oocysts ranging from $2.4 \times 10^{3}-2.4 \times 10^{1}$. Next, each stool sample was placed into a tube $(15 \mathrm{ml})$ and mixed with $0.7 \mathrm{ml}$ redist. $\mathrm{H}_{2} \mathrm{O}$ to obtain a homogeneous suspension. Subsequently, a 7-fold volume of flotation fluid (examination performed separately with each of the tested flotation fluids) was added and the tube was left for 20 minutes. In the next step, the surface liquid of mixture $(150-200 \mu \mathrm{l})$ was taken using a Pasteur pipette and placed into Eppendorf tube. After adding $13 \mathrm{ml}$ of redist. water to each specimen and centrifugation (2,500 $\mathrm{g}$ for $10 \mathrm{~min})$, the supernatant was discarded and pellets were divided into two parts, of which one part was examined by microscopy, while the second part was used for DNA extraction (described below). Each sediment sample was examined by microscopy at $\times 100$ and $\times 400$ magnifications, in triplicate.

To assess the influence of various flotation fluids on the effectiveness of PCR, from the second part of each sediment (approx. $100 \mu \mathrm{l}$ ), DNA was extracted using a commercial set (DNeasy Blood and Tissue Kit, Qiagen), following by ten times of cycle freezing (in liquid nitrogen) and warming $\left(60^{\circ} \mathrm{C}\right.$, in water bath). Next, Real Time PCR (RT) with EvaGreen dye was performed (described below).

To assess the efficiency of $T$. gondii DNA extraction from cat faeces and detection by PCR, selected techniques of DNA isolation and PCR were performed.

\section{Determination of Real Time and nested PCR sensitivity in detection of T. gondii tachyzoites and/or oocysts in water and stool samples}

Water samples spiked with T. gondii tachyzoites and oocysts. One hundred $\mathrm{ml}$ of redist. $\mathrm{H}_{2} \mathrm{O}$ samples were spiked with decreased numbers of $T$. gondii tachyzoites ranging from $10^{6}-10^{1}$, and with decreased numbers of oocysts $(250,100$, $50,20,10,5,2,1)$.

Stool samples spiked with $T$. gondii oocysts. Stool samples $(250 \mathrm{mg}$ ) free of Toxoplasma, were spiked with various numbers of oocysts $(250,100,50,20,10,5,2,1)$. After flotation with $\mathrm{NaNO}_{3}$ (as above described), the collected pellets were disrupted by 10 cycles of freezing (in liquid nitrogen) and warming (at $60^{\circ} \mathrm{C}$, in water bath).

DNA extraction. For assessment of the efficiency of T. gondii DNA detection in faecal samples, two variants of DNA extraction were performed using commercial sets K1 (DNeasy Blood and Tissue Kit (Qiagen), and K2 (QIamp DNA Stool Mini Kit (Qiagen). DNA extraction was performed according to the manufacturers' instructions, with a small modification consisting of an overnight proteinase K digestion step.

Real Time PCR. Amplification of a B1 fragment of gene by Real Time PCR was performed according to the method described by Lin et al. [13], using commercial master mix QI Supermix (Bio-Rad, Hercules, California, USA). The primers used included: TOXO-F (5'-TCCCCTCTGCTGGCGAAAAGT-3', $5 \mu \mathrm{M}$ ), TOXO-R (5'-AGCGTT CGTGGTCAACTATCGATTG-3', $5 \mu \mathrm{M}$ ).

The variants used included:

TaqMan probe - (6FAM-TCTGTGCAAC TTTGGTGTATTCGCAG-TAMRA, $2 \mu \mathrm{M})$. PCR mixture ( $25 \mu$ l of volume) consisted of: $12.5 \mu$ l of master mix, $2.5 \mu \mathrm{l}$ of Toxo F, $2.5 \mu \mathrm{l}$ of Toxo R, $5 \mu \mathrm{l}$ of TaqMan probe and $2.5 \mu \mathrm{l}$ DNA.

EvaGreen fluorescent dye (SsoFast EvaGreen Supermix, BIO-RAD). Composition of the reaction mixture $(20 \mu \mathrm{l}$ of vol.) was as follows: $13.75 \mu \mathrm{l}$ master mix, $2.5 \mu \mathrm{l}$ Toxo F, $2.5 \mu \mathrm{l}$ Toxo R and $1.25 \mu \mathrm{l}$ DNA.

Amplification was carried out in a thermal cycler CFX-96 (Bio-Rad). After initial activation of polymerase at $95^{\circ} \mathrm{C}$ for $10 \mathrm{~min}, 40 \mathrm{PCR}$ cycles of $95^{\circ} \mathrm{C}$ for $15 \mathrm{~s}$ and $60^{\circ} \mathrm{C}$ for $1 \mathrm{~min}$ were performed. The cycle threshold value (CT), indicative of the quantity of target gene at which the fluorescence exceeds a preset threshold, was made automatically by thermo cycler software. After reaching the threshold, the sample was considered positive.

Nested PCR. Detection of the DNA of T. gondii was performed by amplification of 35-fold-repetition of the B1 fragment gene in nested PCR, based on the method by Grigg and Boothroyd [14]. Each PCR reaction (50 $\mu$ l of total 
volume) contained 1.5 U Taq DNA polymerase (Qiagen, Valencia, California, USA), $1 \times$ PCR buffer containing $15 \mathrm{mM}$ $\mathrm{MgCl}_{2}$, dNTPs (in a final concentration of $0.1 \mathrm{mM}$ ) (Thermo Scientific), a set of primers: Pml/S1 and Pml/AS1 or Pml/ S2 and Pml/AS2, nuclease-free water and $5 \mu$ of isolated DNA. The amplification was carried out in TProfessional 48 thermal cycler (Biometra $\mathrm{GmbH}$, Göttingen, Germany) at the following parameters: an initial cycle at $94^{\circ} \mathrm{C}$ for 2 min, followed by 35 cycles of $94^{\circ} \mathrm{C}$ for $30 \mathrm{~s}, 60^{\circ} \mathrm{C}$ for $30 \mathrm{~s}$, and $72^{\circ} \mathrm{C}$ for $90 \mathrm{~s}$. Final extension was performed at $72^{\circ} \mathrm{C}$ for $2 \mathrm{~min}$. The conditions for the second PCR step were the same as for the first, except for the number of cycles that equaled 30. Products of amplification (531 bp) were identified in $2 \%$ agarose gel (Basica LE, Prona, Madrid, Spain), after electrophoresis in standard conditions and staining with ethidium bromide solution $(2 \mu \mathrm{g} / \mathrm{ml})$. As positive controls, the T. gondii DNA isolates of RH (type I), ME49 (type II) and C56 (type III) strains were used. Nuclease-free water was used as a negative control.

Each DNA sample in nested and Real Time PCR was amplified in two repetitions. The result was considered as positive if at least one of the two repetitions of DNA sample gave a positive result.

\section{RESULTS}

\section{Comparison of the effectiveness of flotation with the use of various flotation solutions.}

Microscopy and PCR examination results showed the highest efficiency in oocysts detection using sodium nitrate solution $\left(\mathrm{NaNO}_{3}\right)$ and saccharose as flotation fluids. Lower efficiency and lack of linearity in the detection of subsequent dilutions of oocysts was found with the use of magnesium sulphate $\left(\mathrm{MgSO}_{4}\right)$ and zinc sulphate $\left(\mathrm{ZnSO}_{4}\right)$ (Tab. 1). Since $\mathrm{NaNO}_{3}$ proved to be the most useful for flotation, this flotation liquid was used in the subsequent stages of the study.

\section{Sensitivity of Real Time and nested PCR in the detection of T. gondii tachyzoites and/or oocysts in water and stool samples}

Sensitivity of PCR in detection of $T$. gondii tachyzoites and oocysts in water samples. The limit of detection (LD) for T. gondii tachyzoites spiked to water samples $(100 \mu \mathrm{l})$ was determined on $10^{2}$ tachyzoites in RT test (in both EvaGreen and TaqMan variants) (Tabs. 2, 3) and $2 \times 10^{2}$ tachyzoites in nested PCR (Fig. 1), respectively. LD for oocysts in water samples $(100 \mu \mathrm{l})$ amounted 1 and 50 oocyst in RT (with regard to the DNA extraction kit used) (Tab. 4) and 2-20 oocysts in nested PCR. However, for some repetitions of samples spiked with 5 and 10 oocysts, negative results were obtained. A significant difference was found in the sensitivity of RT depending on kit used for extraction DNA; the K1 kit seems to be more efficient in extracting of DNA from $T$. gondii oocysts suspended in water samples (Tab. 4).

PCR sensitivity in detection of T. gondii oocysts spiked in cat stool samples. Comparison of T. gondii DNA amplification efficiency of stool samples spiked with oocysts, with the use of two commercial DNA extraction sets and two PCR techniques, showed differences in the limits of detection for DNA T. gondii.
Table 1. Effectiveness of flotation and PCR depending of the flotation fluids used

\begin{tabular}{|c|c|c|c|c|}
\hline \multirow{2}{*}{ Flotation fluid } & \multirow{2}{*}{$\begin{array}{l}\text { No. of spiked } \\
\text { oocysts }\end{array}$} & \multirow{2}{*}{$\frac{\text { Results of microscopy }}{\text { No. of oocysts }}$} & \multicolumn{2}{|c|}{ Results of Real time PCR } \\
\hline & & & $+/(-)^{* *}$ & $C_{t}^{\#}$ \\
\hline \multirow{5}{*}{ Saccharose } & $2.4 \times 10^{3}$ & 19 & + & 38.8 \\
\hline & $1.2 \times 10^{3}$ & 8 & $(-)$ & $\mathrm{N} / \mathrm{A}$ \\
\hline & $0.6 \times 10^{2}$ & 0 & $(-)$ & $\mathrm{N} / \mathrm{A}$ \\
\hline & $0.3 \times 10^{2}$ & 1 & $+(-)^{\mathrm{E}}$ & 47.2 \\
\hline & $2.4 \times 10^{1}$ & 0 & $+(-)$ & 47.3 \\
\hline \multirow{5}{*}{$\mathrm{NaNO}_{3}$} & $2.4 \times 10^{3}$ & 13 & + & 36.4 \\
\hline & $1.2 \times 10^{3}$ & 8 & $+(-)$ & 48.5 \\
\hline & $0.6 \times 10^{2}$ & 5 & + & 37.5 \\
\hline & $0.3 \times 10^{2}$ & 2 & $(-)$ & $\mathrm{N} / \mathrm{A}$ \\
\hline & $2.4 \times 10^{1}$ & 0 & $+(-)$ & 47.4 \\
\hline \multirow{5}{*}{$\mathrm{ZnSO}_{4}$} & $2.4 \times 10^{3}$ & 0 & $(-)$ & $\mathrm{N} / \mathrm{A}$ \\
\hline & $1.2 \times 10^{3}$ & 9 & $+(-)$ & 48.1 \\
\hline & $0.6 \times 10^{2}$ & 1 & $(-)$ & N/A \\
\hline & $0.3 \times 10^{2}$ & 0 & $(-)$ & $\mathrm{N} / \mathrm{A}$ \\
\hline & $2.4 \times 10^{1}$ & 0 & $+(-)$ & 46.5 \\
\hline \multirow{5}{*}{$\mathrm{MgSO}_{4}$} & $2.4 \times 10^{3}$ & 2 & $+(-)$ & 45,5 \\
\hline & $1.2 \times 10^{3}$ & 1 & $(-)$ & $\mathrm{N} / \mathrm{A}$ \\
\hline & $0.6 \times 10^{2}$ & 0 & + & 40.9 \\
\hline & $0.3 \times 10^{2}$ & 3 & $+(-)$ & 43.6 \\
\hline & $2.4 \times 10^{1}$ & 1 & $(-)$ & $\mathrm{N} / \mathrm{A}$ \\
\hline
\end{tabular}

-Summarized numbers of oocysts detected in $60 \mu \mathrm{l}(3 \times 20 \mu \mathrm{l})$ of sediment after flotation; "Result of examination $100 \mu \mathrm{l}$ of sediment after flotation;

\#Threshold Cycle

E Results obtained after increasing cycles of amplification (more than 40 ) and recognized as equivocal

$\mathrm{N} / \mathrm{A}$ - not applicable

Table 2. $C_{t}$ results of Real time PCR with EvaGreen (water sample spiked with tachyzoites)

\begin{tabular}{cccc}
\hline \multirow{2}{*}{ Tachyzoites } & Fluorophore & Threshold Cycle $\left(\mathrm{C}_{\mathrm{t}}\right)$ & Result \\
\hline $10^{6}$ & EvaGreen & 20.66 & + \\
\hline $10^{5}$ & EvaGreen & 23.06 & + \\
\hline $10^{4}$ & EvaGreen & 24.93 & + \\
\hline $10^{3}$ & EvaGreen & 28.61 & + \\
\hline $10^{2}$ & EvaGreen & 36.69 & + \\
\hline $10^{1}$ & EvaGreen & $\mathrm{N} / \mathrm{A}$ & $(-)$ \\
\hline
\end{tabular}

N/A - not applicable

Table 3. $C_{t}$ results of Real Time PCR with TaqMan (water sample spiked with tachyzoites).

\begin{tabular}{cccc}
\hline Tachyzoites & Probe & Threshold Cycle $\left(\mathrm{C}_{\mathrm{t}}\right)$ & Results \\
\hline $10^{6}$ & TaqMan & 16.78 & + \\
\hline $10^{5}$ & TaqMan & 22.86 & + \\
\hline $10^{4}$ & TaqMan & 27.79 & + \\
\hline $10^{3}$ & TaqMan & 32.51 & + \\
\hline $10^{2}$ & TaqMan & 35.99 & + \\
\hline $10^{1}$ & TaqMan & N/A & $(-)$ \\
\hline
\end{tabular}

N/A - not applicable 
Table 4. Comparison of Real Time PCR (TaqMan) sensitivity (limit of detection) for water samples spiked with T. gondii oocysts using K1 and K2 DNA extraction kits

\begin{tabular}{ccccc}
\hline \multirow{2}{*}{$\begin{array}{c}\text { No. of spiked } \\
\text { oocysts }\end{array}$} & \multicolumn{3}{c}{ K1 } & \multicolumn{3}{c}{ K2 } \\
\cline { 2 - 5 } & $C_{t}$ & Results + - & $C_{t}$ & Results + - \\
\hline 250 & 31.59 & + & 35.99 & + \\
\hline 100 & 32.65 & + & 36.56 & + \\
\hline 50 & 33.63 & + & 37.45 & + \\
\hline 20 & 34.95 & + & N/A & $(-)$ \\
\hline 10 & 36.11 & + & N/A & $(-)$ \\
\hline 5 & 38.15 & + & N/A & $(-)$ \\
\hline 2 & 38.28 & + & N/A & $(-)$ \\
\hline 1 & 39.85 & \pm & N/A & $(-)$ \\
\hline
\end{tabular}

N/A - not applicable

Table 5. Comparison of Real time PCR sensitivity (limit of detection) for cat stool samples spiked with $T$. gondii oocysts using K1 and K2 DNA extraction kits

\begin{tabular}{ccccc}
\hline $\begin{array}{c}\text { No. of spiked } \\
\text { oocysts }\end{array}$ & Taq & Eva & Taq & Eva \\
\hline & \multicolumn{4}{c}{$\mathrm{C}_{\mathrm{t}} /$ result + /- } \\
\hline 250 & $34.18 /+$ & $\mathrm{n} / \mathrm{e}$ & $33.06 /+$ & $38.49 /+$ \\
\hline 100 & $\mathrm{~N} / \mathrm{A}$ & $\mathrm{n} / \mathrm{e}$ & $38.03 /+$ & $39.24 /+$ \\
\hline 50 & $\mathrm{~N} / \mathrm{A}$ & $\mathrm{n} / \mathrm{e}$ & $\mathrm{N} / \mathrm{A}$ & $39.72 /+$ \\
\hline 20 & $\mathrm{~N} / \mathrm{A}$ & $\mathrm{n} / \mathrm{e}$ & $\mathrm{N} / \mathrm{A}$ & $\mathrm{N} / \mathrm{A}$ \\
\hline 10 & $\mathrm{~N} / \mathrm{A}$ & $\mathrm{n} / \mathrm{e}$ & $\mathrm{N} / \mathrm{A}$ & $\mathrm{N} / \mathrm{A}$ \\
\hline 5 & $\mathrm{~N} / \mathrm{A}$ & $\mathrm{n} / \mathrm{e}$ & $37.86 /+$ & $\mathrm{N} / \mathrm{A}$ \\
\hline 2 & $\mathrm{~N} / \mathrm{A}$ & $\mathrm{n} / \mathrm{e}$ & $\mathrm{N} / \mathrm{A}$ & $\mathrm{N} / \mathrm{A}$ \\
\hline 1 & $\mathrm{~N} / \mathrm{A}$ & $\mathrm{n} / \mathrm{e}$ & $38.94 /+$ & $\mathrm{N} / \mathrm{A}$ \\
\hline
\end{tabular}

N/A - no amplification

n/e - not examined

With the use of the K1 extraction set, LD in RT was high and amounted 250 oocysts $/ 250 \mathrm{mg}$ of stool (Tab. 5), whereas in nested PCR, LD was determined as 5 oocysts $/ 250 \mathrm{mg}$ stool sample. However, for some repetitions of samples spiked with 10-50 oocysts, negative results were obtained (Fig. 2). In this step of the study, EvaGreen RT variant was not performed.

Using the K2 DNA extraction kit, in the TaqMan RT variant, the limit of detection (LD) was determined on 1 oocyst $/ 250 \mathrm{mg}$ of stool sample. However, for some intermediate numbers of oocysts, negative results were obtained. In EvaGreen RT, LD was determined as 50 oocysts/250 mg of stool sample (Tab. 5). In the nested PCR, using the K2 extraction kit, LD was determined as 50 oocysts/250 mg of stool sample (Fig. 3).

\section{DISCUSSION}

To-date, the results of serological examination of cats are not fully informative about the possibility of current excretion of oocysts with their faeces [15]. Infected cats excrete oocysts for a short period of about 1-3 weeks, mostly once in their lifetime [16] what causes difficulty in diagnosis during single faecal examination. Due to difficulties in T. gondii oocysts detection during routine microscopy examination (morphological T. gondii oocysts similarity to other protozoa,

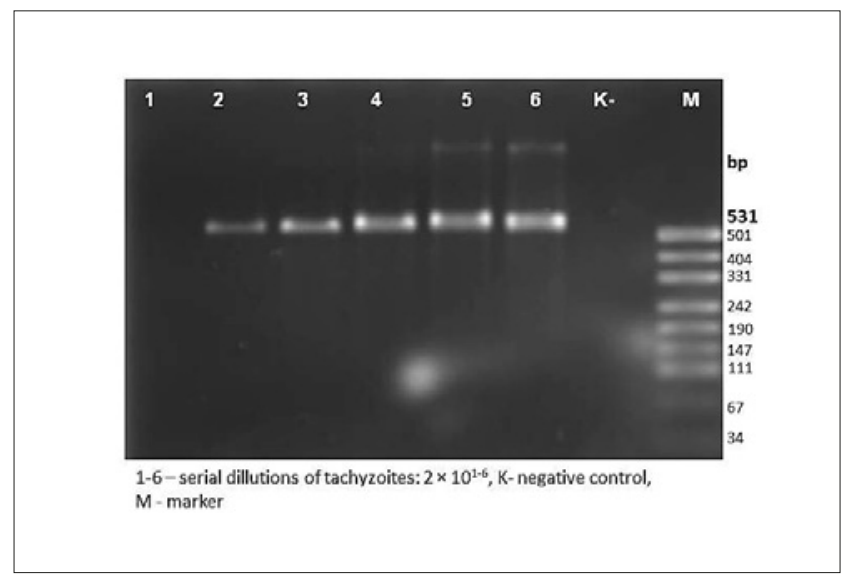

Figure 1. Results of nested PCR (B1 gene fragment) for water samples with T. gondii tachyzoites

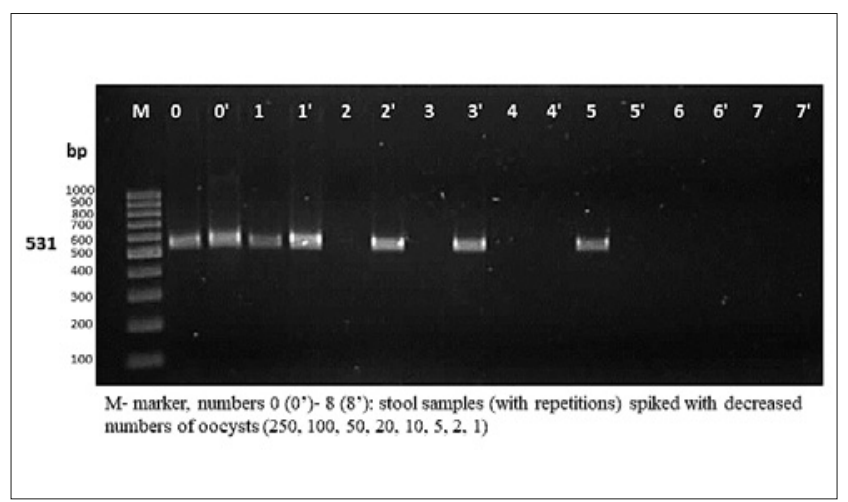

Figure 2. Results of nested PCR (B1 gene fragment) for stool samples spiked with T. gondii oocysts (K1 DNA extraction kit)

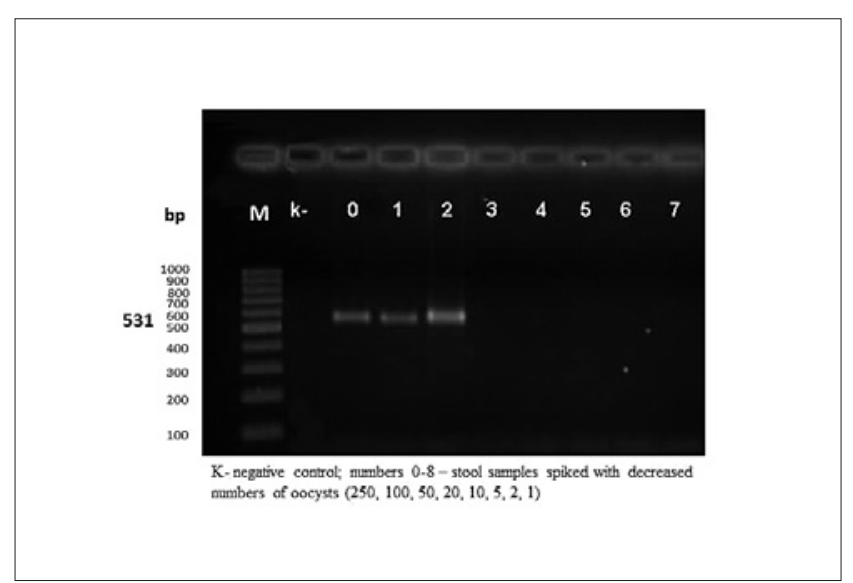

Figure 3. Results of nested PCR (B1 gene fragment) for stool samples spiked with T. gondii oocysts (K2 DNA extraction kit)

i.e. H. hammondi, Cystoisospora spp., Sarcocystis spp.) [11, 17], the additional molecular examination of faeces may be useful for confirming the diagnosis. The presented study is focused on the effects of various flotation, DNA extraction and PCR methods on the efficiency of microscopic and molecular diagnostics in the detection of $T$. gondii in cat faeces.

During the first stage of the study, the efficacy of flotation and PCR was compared using selected flotation solutions. The initial results showed that $\mathrm{NaNO}_{3}$ was the most useful as the flotation fluid due to the lack of any visible, negative effect on the oocysts structure under microscope examination, 
and the best amplification efficacy in PCR, in relation to the results obtained in this study compared with other flotation fluids. Admittedly, the use of sugar as the flotation solution allowed for the detection of the largest number of oocysts by microscopy; however, in PCR negative results were obtained for low concentrations of oocysts. Nevertheless, the equivocal (positive) results were obtained after an additional increase the cycles, above 40 . On the other hand, increasing the cycles above the number estimated during the validation process, may cause false positive results.

Numerous studies have been published analyzing effectiveness of the concentration method for the detection of parasitic protozoa in stool samples $[18,19,20]$. Several studies concerning the molecular investigation of parasitic protozoa in stool samples have also been published [21, $22,23]$. These studies were generally intended for specific parasites protozoa. Furthermore, the presence of PCR inhibitors in stool samples has frequently been associated with the occurrence of sensitivity reduction, and may lead to false negative results for PCR $[24,25]$.

The presented results of PCR for water samples spiked with T. gondii tachyzoites and oocysts showed a good sensitivity of used techniques. In both variants of RT (TaqMan and EvaGreen), the limit of detection was determined at $10^{2}$ tachyzoites and 1-50 oocyst (regarding the DNA extraction variant used). In nested PCR, the limit of detection was relatively higher and amounted $2 \times 10^{2}$ tachyzoites and 2-20 oocysts. These results confirm the greater sensitivity of the RT technique, compared to nested PCR, especially in the detection of $T$. gondii vegetative forms (tachyzoites) using routine DNA isolation methods.

Detection of T. gondii DNA extracted from oocysts is more difficult due to the need for an initial oocysts wall disruption. In RT, examinations of water samples spiked with Toxoplasma oocysts, where DNA was extracted using DNeasy Blood and Tissue Kit, the sensitivity of the test was high and amounted 1 oocyst / per sample. Nested PCR showed similar sensitivity - LD $=2$ oocysts / per sample, but negative results for intermediate concentrations of oocysts were obtained. In the examination of water samples spiked with oocysts, where DNA was isolated by Qiamp DNA Stool Mini Kit, in two variants of RT (TaqMan probe and EvaGreen dye) similar results were obtained. The limit of detection was determined at 50 oocysts / per $250 \mathrm{mg}$ stool sample, and was higher compared to the K1 DNA extraction kit.

The results of RT for stool samples spiked with Toxoplasma oocysts showed more differences in the obtained results. In comparing the efficiency of the two DNA extraction kits for stool samples, the higher sensitivity of PCR reaction was stated using the Qiamp DNA Stool Mini Kit than the DNeasy Blood and Tissue Kit. The limit of detection was determined from 1 (TaqMan) to 50 (EvaGreen) oocysts and 250 oocyst / per sample, respectively. However, using the K2 kit, the negative results for intermediate concentrations of oocysts (50,20, 10 oocysts / sample) were obtained. In nested $\mathrm{PCR}$, samples isolated with both extraction kits (K1 and K2) showed good sensitivity and LD was determined at 5 and 50 oocysts/250 mg stool sample, respectively.

The initial results of the presented study may indicate the need for further research using different variants of methods and flotation solutions to improve sensitivity of T. gondii detection in cat faeces. Due to the specificity of the research material, their heterogeneity of composition, rich microflora and the presence of PCR inhibitors, the effective isolation and detection of specific genetic material is difficult. Inhibitors present in cat faeces significantly reduce the sensitivity of PCR reaction, especially in the RT variant. Hence, using the appropriate DNA extraction methods, including absorption of inhibitors, it seems necessary to improve the efficacy of PCR. The results obtained from the RT for samples purified from inhibitors by using Qiamp DNA Stool Mini Kit, may confirmed this thesis. However, the process of inhibitors elimination can also reduce the amount of total isolated DNA, as indicated by the RT results for water samples spiked with oocysts, where threshold for positive results showed a higher $\mathrm{C}_{t}$ value (K2 kit) compared to samples isolated without additional step of inhibitor removing (K1 kit).

Methodological factors such as the sensitivity of the method to detect T. gondii DNA, may strongly contribute to variability between studies [26]. For example, Lélu et al. [27] in examination of soil samples on the presence of T. gondii oocysts, determined the sensitivity of the DNA extraction method and RT PCR at 10 - 100 oocysts per gram of soil, whereas the method used by Wang et al. [28] allowed the detection of up to 100 oocysts $/ 5 \mathrm{~g}$ of soil. To- date, Salant et al. $[5,29]$ compared different techniques for oocysts detection in faeces. In this experiment, cat stool samples were examined by PCR targeting B1 gene. LD was determined as few as 1-2 oocysts per $200 \mathrm{ml}$ faeces with $50 \%$ reproducibility and with $100 \%$ reproducibility for samples spiking with 5,10 , and 50 oocysts. To the initial disruption of the oocyst wall, these authors vortexed sample with glass beads and performed three freeze-thaw cycles. In the current study, instead of initial mechanical disruption, the increased number of nitrogen-heating cycles to 10 was performed.

Several methods for inhibitors removal from fecal samples have been used to improve the efficacy of PCR [30, 31]. With this in mind, in the presented study a commercial kit designed to overcome inhibition (R2) was used. Also in the presented study, PCR targeting the B1 gene, having 35 repetition in $T$. gondii genome, was applied. In a recent study by Veronesi et al. [23], in which as the targets in PCR the B1 gene and the 529-bp repetitive element (RE) were used, the lower sensitivity of the 529-bp RE-PCR assay in comparison to the B1-PCR was determined. In the study by Chemoh et al. [11], a comparative analysis on the occurrence of T. gondii in cat faeces using PCR assays targeting the 529-bp RE and ITS1 regions was performed, and showed a seven times higher detection by ITS-1 primers than the 529- bp RE set primers.

Applying the PCR technique for the detection of T. gondii DNA in cat faeces can be suitable for screening examination due to the easy and rapid handling of a large number of samples, and obtaining results with a high detection sensitivity, specificity and reproducibility. Moreover, a sensitive PCR test may be able to detect low numbers of shedding oocysts, which are usually undetectable using traditional microscopy.

\section{CONCLUSIONS}

The present study shows the usefulness of flotation with saturated $\mathrm{NaNO}_{3}$ to prior concentration of $T$. gondii oocysts for further microscopic and molecular diagnostics. The effects of the application of selected flotation solutions used in parasitological investigation on the efficacy of the T. gondii 
detection in faeces by PCR was also presented. Results of the study show that the most effective methods for the detection of T. gondii in cat faeces seems to be centrifugal flotation with $\mathrm{NaNO}_{3}$, followed by DNA extraction with the removal of inhibitors (K2 kit) and Real Time PCR targeting the B1 gene. These methods are relatively inexpensive and suitable for epidemiological monitoring and clinical investigations.

\section{REFERENCES}

1. Dubey JP, Beattie CP. Toxoplasmosis of Animals and Man. 1st edition. Boca Raton: CRC Press, 1988.

2. Dubey JP, Graham DH, De Young RW, Dahl E, Eberhard ML, Nace EK, Won K, Bishop H, Punksody G, Streekmar C, Vianna MC, Shen SK, Kwok OC, Summers JA, Demarais S, Hill DE, Chirukandoth S, Dubey JP. Biology and epidemiology of Toxoplasma gondii in man and animals. Anim Health Res Rev. 2005; 6: 41-61.

3. Tenter AM, Heckeroth AR, Weiss LM. Toxoplasma gondii: from animals to humans. Int J Parasitol. 2000; 30: 1217-1258.

4. Sroka J, Wójcik-Fatla A, Szymańska J, Dutkiewicz J, Zając V, Zwoliński J. The occurrence of Toxoplasma gondii infection in people and animals from rural environment of Lublin region - estimate of potential role of water as a source of infection. Ann Agric Environ Med. 2010; 17: 111-118.

5. Salant H, Spira D, Hamburger J. A comparative analysis of coprologic diagnostic methods for detection of Toxoplasma gondii in cats. Am J Trop Med Hyg. 2010; 82: 865-870.

6. Dubey JP, Frenkel JK. Feline toxoplasmosis from acutely infected mice and the development of Toxoplasma cysts. J Protozool. 1976; 23: 537-546.

7. Dubey JP. Infectivity and pathogenicity of Toxoplasma gondii oocysts for cats. J Parasitol. 1996; 82: 957-961.

8. Singh B. Molecular methods for diagnosis and epidemiological studies of parasitic infections. Int. J. Parasitol. 1997; 27: 1135-1145.

9. Orlandi PA, Lampel KA. Extraction-free, filter-based template preparation for rapid and sensitive PCR detection of pathogenic parasitic protozoa. J Clin Microbiol. 2000; 38: 2271-2277.

10. Mancianti F, Nardoni S, Mugnaini L, Zambernardi L, Guerrini A, Gazzola V, Papini RA. A retrospective molecular study of select intestinal protozoa in healthy pet cats from Italy. J Feline Med Surg. 2015; 17: 163-167.

11. Chemoh W, Sawangjaroen N, Nissapatorn V, Sarmwittayawon N. Molecular investigation on the occurrence of Toxoplasma gondii oocysts in cat faeces using TOX-element and ITS-1 region targets. Vet J. 2016; 215: $118-122$.

12. Schares G, Pantchev N, Barutzki D, Heydorn AO, Bauer C, Conraths FJ. Oocysts of Neospora caninum, Hammondia heydorni, Toxoplasma gondii and Hammondia hammondi in faeces collected from dogs in Germany. Int J Parasitol. 2005; 35: 1525-1537.

13. Lin MH, Chen TC, Kuo TT, Tseng CC, Tseng CP. Real-time PCR for quantitative detection of Toxoplasma gondii. J Clin Microbiol. 2000; 38: 4121-4125.
14. Grigg ME, Boothroyd JC. Rapid identification of virulent type I strains of the protozoan pathogen Toxoplasma gondii by PCR restriction fragment length polymorphism analysis at the B1 gene. J Clin Microbiol. 2001; 39: 398-400.

15. Dubey JP, Frenkel JK. Cyst-induced toxoplasmosis in cats. J. Protozool. 1972; 19: 155-177.

16. Dubey JP. Toxoplasmosis. J Am Vet Med Assoc. 1994; 205: 1593-1598.

17. Barutzki D., Schaper R. Endoparasites in dogs and cats in Germany 1999-2002. Parasitol Res. 2003; 90(Suppl. 3): 148-150.

18. Stojecki K, Sroka J, Karamon J, Kusyk P, Cencek T. Influence of selected stool concentration techniques on the effectiveness of PCR examination in Giardia intestinalis diagnostics. Pol J Vet Sci. 2014; 17: 19-25.

19. Weber R, Bryan RT, Juranek DD. Improved stool concentration procedure for detection of Cryptosporidium oocysts in fecal specimens. J Clin Microbiol. 1992; 30: 2869-2873.

20. Bukhari Z, Smith HV. Effect of three concentration techniques on viability of Cryptosporidium parvum oocysts recovered from bovine feces. J Clin Microbiol. 1995; 33: 2592-2595.

21. Nichols RA, Moore JE, Smith HV. A rapid method for extracting oocyst DNA from Cryptosporidium-positive human faeces for outbreak investigations. J Microbiol Methods. 2006; 65: 512-524.

22. Platts-Mills JA, Operario DJ, Houpt ER. Molecular diagnosis of diarrhea: current status and future potential. Curr Infect Dis Rep. 2012; 14: 41-46.

23. Veronesi F, Santoro A, Milardi GL, Diaferia, M, Morganti G, Ranucci, D, Gabrielli S. Detection of Toxoplasma gondii in faeces of privately owned cats using two PCR assays targeting the B1 gene and the 529-bp repetitive element. Parasitol Res. 2017; 116: 1063-1069.

24. Monteiro L, Bonnemaison D, Vekris A, Petry KG, Bonnet J, Vidal R, Cabrita J, Megraud F. Complex polysaccharides as PCR inhibitors in feces: Helicobacter pylori model. J Clin Microbiol. 1997; 35: 995-998.

25. Schrader C, Schielke A, Ellerbroek L, Johne R. PCR inhibitorsoccurrence, properties and removal. J Appl Microbiol. 2012; 113: 1014-1026.

26. Gotteland C, Gilot-Fromont E, Aubert D, Poulle ML, Dupuis E, Dardé ML, Villena I. Spatial distribution of Toxoplasma gondii oocysts in soil in a rural area: influence of cats and land use. Vet Parasitol. 2014; 205: 629-637.

27. Lélu M, Gilot-Fromont E, Aubert D, Richaume A, Afonso E, Dupuis, E, Gotteland, C, Marnef F, Poulle ML, Dumetre A, Thulliez P, Darde ML, Villena I. Development of a sensitive method for Toxoplasma gondii oocyst extraction in soil. Vet Parasitol. 2011; 183: 59-67.

28. Wang M, Meng P, Ye Q, Pu YH, Yang XY, Luo JX, Zhang DL. Detection of Toxoplasma gondii oocysts in soils in Northwestern China using a new semi-nested PCR assay. BMC veterinary research, 2014; 10: 238.

29. Salant H, Markovics A, Spira DT, Hamburger J. The development of a molecular approach for coprodiagnosis of Toxoplasma gondii. Vet Parasitol. 2007; 146: 214-220.

30. Uwatoko K, Sunairi M, Yamamoto A, Nakajima M, Yamaura K. Rapid and efficient method to eliminate substances inhibitory to the polymerase chain reaction from animal fecal samples. Vet Microbiol. 1996; 52:73-79.

31. da Silva AJ, Bornay-Llinares FJ, Moura IN, Slemenda SB, Tuttle JL, Pieniazek NJ. Fast and reliable extraction of protozoan parasite DNA from fecal specimens. Mol Diagn. 1999; 1: 57-64. 